\title{
Exploratory analyses of migration timing and morphometrics of the Dunnock (Prunella modularis)
}

\author{
Andrea Harnos ${ }^{1 *}$, Péter Fehérvári ${ }^{1,2}$, Imre Sándor Piross ${ }^{1}$, \\ Nóra ÁGH ${ }^{1}$, Zsolt KARCZA ${ }^{3}$, Krisztina KONRÁD ${ }^{1} \&$ Tibor CsÖRGÖ ${ }^{4}$
}

Received: November 26, 2016-Accepted: December 14, 2016

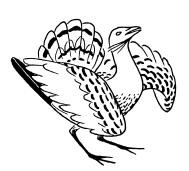

Andrea Harnos, Péter Fehérvári, Imre Sándor Piross, Nóra Ágh, Zsolt Karcza, Krisztina Konrád \& Tibor Csörgő 2016. Exploratory analyses of migration timing and morphometrics of the Dunnock (Prunella modularis). - Ornis Hungarica 24(2): 127-144.

Abstract Ornithological studies often rely on large temporal scale ringing datasets as source of information. However, basic descriptive statistics of collected data are rarely provided. In order to fill this gap, here we present the second item of a series of exploratory analyses of migration timing and body size measurements of the most frequent Passerine species at a ringing station located in Central Hungary (1984-2015). First, we give a concise description of foreign ring recoveries of the Dunnock in relation to Hungary. We then shift focus to data of 11,617 individuals deriving from the ringing station, where birds have been trapped, handled and ringed with standardized methodology since 1984. Timing is described through annual and daily capture and recapture frequencies and their descriptive statistics. We show annual mean arrival dates within the study period and we present the cumulative distribution of first captures with stopover durations. We present the distributions of wing, third primary, tail length and body mass, and the annual means of these variables. Furthermore, we show the distribution of individual fat and muscle scores, and the distribution of body mass within each fat score category. We distinguish migration periods (spring and autumn), and age groups (i.e. juveniles and adults). Our aim is to provide a comprehensive overview of the analysed variables. However, we do not aim to interpret the obtained results, merely draw attention to interesting patterns, that may be worth exploring in detail. Data used here are available upon request for further analyses.

Keywords: Hedge Accentor, Hedge Sparrow, Hedge Warbler, Ócsa Bird Ringing Station, wing, third primary, tail length, body mass, fat, muscle, bird banding, capture-recapture, long term data, meta-analyses

Összefoglalás Madártani tanulmányokban gyakran elemeznek hosszútávú madárgyưrúzési adatsorokat, de az alapvetô leíró statisztikák és exploratív elemzések általában nem hozzáférhetőek. E hiányt pótolandó, cikksorozatot indítunk, melyben egy közép-magyarországi gyưrúző állomáson leggyakrabban előforduló énekesmadár fajok vonulás időzítésének és testméreteinek exploratív elemzéseit közöljük (1984-2015). A sorozat második tagjaként szolgáló jelen cikkben először áttekintjük az erdei szürkebegy magyar gyưrús külföldi és külföldi gyưrús magyarországi megkerüléseit, majd rátérünk a faj egy magyarországi, 1984 óta standard módszerekkel dolgozó gyưrúzőállomásról származó 11617 egyedétől származó adatának elemzésére. Az időzítés jellemzéséhez az éves és a napi átlagos első megfogások és visszafogások leíró statisztikái mellett megmutatjuk az évenkénti átlagos érkezési időket és azok változását. Az éven belüli időzítést az első megfogások kumulatív eloszlásával ábrázoljuk feltüntetve a tartózkodási időket is. Közöljük a szárnyhossz, a harmadik evező hossz, a farokhossz és testtömeg leíró statisztikáit. Ábrákon bemutatjuk ezen változók éves átlagait, a zsír- és izomkategóriák gyakorisági eloszlását, valamint a testtömegek eloszlását zsírkategóriák szerinti bontásban. Az elemzésben elkülönítjük az egyes vonulási idôszakokat (tavasz, ôsz) és a korcsoportokat (fiatal, öreg). Célunk a vizsgált változók átfogó bemutatása és a bennük található mintázatok feltárása volt az eredmények interpretálása nélkül. Kérésre a cikkhez felhasznált adatsort rendelkezésre bocsátjuk. 
Kulcsszavak: Ócsai Madárvárta, szárnyhossz, harmadik evező hossza, farokhossz, testtömeg, zsír, izom, madárgyưrűzés, hosszútávú adatsor, meta-analízis

\footnotetext{
${ }^{1}$ Department of Biomathematics and Informatics, University of Veterinary Medicine, 1078 Budapest, István utca 2., Hungary, e-mail: harnos.andrea@univet.hu

${ }^{2}$ Department of Zoology, Hungarian Natural History Museum, 1088 Budapest, Baross utca 13., Hungary

${ }^{3}$ Hungarian Bird Ringing Center, BirdLife Hungary, 1121 Budapest, Költő utca 21., Hungary

${ }^{4}$ Department of Anatomy, Cell- and Developmental Biology, Eötvös Loránd University, 1117 Budapest, Pázmány Péter sétány 1/C, Hungary

*corresponding author
}

\section{Introduction}

Bird ringing or banding is one of the principal and oldest methods in use to study various aspects of avian populations (Robinson et al. 2009). Overwhelming volume of data has been collected in over a century of bird ringing, and has been used excessively in a diverse array of disciplines. However, compared to the amount of data available throughout the world, concise descriptive information suitable for meta- or comparative analyses is sporadically available (Gienapp et al. 2007, Harnos et al. 2015). Though purely descriptive studies are often hard to publish within the framework of current hypothesis-focused science, we feel that such studies may well play an outstanding role in generating new hypotheses for future studies. For this purpose, it is essential that descriptive studies must apply the most appropriate statistical methodologies (Harnos et al. 2015, 2016). The bulk of currently available ringing data is often derived from large temporal scale projects like permanent ringing stations, where massive amount of individuals of various species are trapped simultaneously (Csörgő et al. 2016). These projects generally apply standardized and similar methodologies in trapping, handling and data collection, thus information derived from these sites is suitable for location-wise comparisons (Schaub \& Jenni 2000, Marra et al. 2004, Schaub et al. 2008, Tøttrup et al. 2010).

Here we present exploratory and descriptive statistics on the migration timing and morphometrics of the Dunnock between 1984-2015 from a Central European ringing station (Ócsa Bird Ringing Station, Hungary, see Csörgó et al. 2016 for details).

The Dunnock is a small, sexually monomorphic omnivorous passerine of the Prunellidae family. The plumage on the chest and on the head is mostly blueish-gray. The back, and the sides of the breasts are brown with dark streaks, although individuals can differ a lot in their looks. The juveniles are similar in appearance, but the gray parts are paler while the striations are more dominant (Cramp 1988, Svensson 1992, Demongin 2016).

The Dunnock is polytipical, with 8 descriped subspecies, namely $P$. m. modularis, $P$. m. hebridium, P. m. occidentalis, P. m. mabbotti, P. m. meinertzhageni, P. m. fuscata, $P$. m. euxina, P. m. obscura. The subspecies are quite similar in their appearance, making the identification of a single individual almost impossible. Wing morphology slightly differs among the subspecies, migratory ones tend to have longer, skewer, more pointed 
wings compared to the residents' shorter, rounded wings (Cramp 1988, Svensson 1992, Demongin 2016).

It's breeding distribution ranges across mainly in the temperate and marginally in the subarctic and boreal zones of the Palearctic Region (Cramp 1988). The nominate subspecies occupies the majority of the breeding range. $P$. $m$. hebridium breeds in the Inner, Outer Hebrids and Orkney, $P$. m. occidentalis in the British Isles, $P$. m. mabotti in the Iberian Peninsula, in South France and in South Italy. P. m. meinertzhageni can be found in the Balkans, $P$. $m$. fuscata in the Crimean Peninsula, $P$. $m$. euxina in the north-western parts of the Anatolian Peninsula, while P. m. obscura breeds in the Eastern-Anatolian Peninsula, besides Northern-Iran, Caucasus and the Crimean Peninsula. The breeding range of the $P$. m. modularis is apparently expanding north in Fennoscandia, presumably due to modern forestry practices (Vogel \& Tuomenpuro 1997, Fransson \& Hall-Karlsson 2008). The species was also introduced to New Zealand (Cramp 1988, Hatchwell 2005).

The Dunnock is classified as Least Concern in the IUCN Red List, however the European population is moderately decreasing (BirdLife International 2016).

In Hungary, the first record of the nominate subspecies was recorded in 1934 (Studinka 1931-34 in Magyar et al. 1998, Hadarics \& Zalai 2008), but it is known as regular breeder only since the early 1960's (Rapos 1962, Szabó 1962 in Magyar et al. 1998, Hadarics \& Zalai 2008). Today the Hungarian population shows a moderate decrease and is estimated to 1200-1500 pairs. The species is protected in Hungary (BirdLife Hungary 2016).

Breeding habitats of Dunnock is deciduous and coniferous woods with dense undergrowth (Cramp 1988). Their mating system is complex, both monogamy and various forms of poligamy (poliandry, poligyny, poligynandry) may occur (Davies \& Lundberg 1984, Davies 1985, 1986, Davies \& Houston 1986, Hatchwell \& Davies 1990, 1992, Santos \& Nakagawa 2013).

Various migratory strategies can be found among the subspecies (resident, altitudinal migrant, partial or obligatory migrant). The $P$. $m$. hebridium and the $P$. m. mabotti are residents. The $P$. m. occidentalis makes short, dispersive movements, although a few indviduals originated from the British Isles were found in Northern France, Belgium, the Netherlands, Denmark, Germany and Norway (Hartly 2002). The P. m. euxina and the P. $m$. obscura are residents or partial migrants. The nominate subspecies is an obligatory migrant in the northern parts of its breeding area, and partial migrant in the south (Cramp 1988). The speed of the migration is relatively slow $(34.5 \mathrm{~km} /$ day on average; Fransson \& Hall-Karlsson 2008), they take small steps, mostly at dawn (Dorka 1966 in: Bingman \& Wiltschko 1988). Although the species migrates on a broad front, individual populations use narrow, defined routes (Zaniewicz \& Busse 2008). The general bearing of the autumn migration is south-west across the whole breeding range. North-eastern populations (Finland, Valkama et al. 2014) are the first to depart in mid-September, while the north-western birds take off in late September, early October (Bønløkke et al. 2006, Fransson \& HallKarlsson 2008). These populations migrate through the Baltic Sea (Sokolov et al. 1999, Zaniewicz \& Busse 2008). Arriving to the wintering grounds takes place between Septem- 
ber and November depending on the location of the breeding and wintering sites (Schubert et al. 1986, Pons 2001, Spina \& Volponi 2009).

Migrating populations overwinter mostly in southern Europe (Malczewski \& Pukinsky 1983, Cramp 1988, Fransson \& Hall-Karlsson 2008, Spina \& Volponi 2009, Barišić 2013, Valkama et al. 2014), a few recaptures were reported from Morocco and Algeria (Bairlein et al. 2014). Qualitative overview of the recapture patterns of Dunnocks from Russia (Malczewski \& Pukinsky 1983), Finland (Valkama et al. 2014), Sweden (Fransson \& Hall-Karlsson 2008), Denmark (Bønløkke et al. 2006), Germany (Bairlein et al. 2014), Czech Republic (Hromádko 2008), Croatia (Barišić 2013), Italy (Spina \& Volponi 2009) revealed, that there is strong migratory connectivity of breeding populations. The breeding range of the Swedish birds ranges from Denmark to North Spain. Their recovery patterns further indicates that in the last decades the wintering range gradually shifted north for this population (Fransson \& Hall-Karlsson 2008). Individual inter-annual wintering site fidelity is high, especially in the southern regions (Benvenuti \& Ioalè 1980, Ioale \& Benvenuti 1983, Schwabl et al. 1991, Pons 2001, Spina \& Volponi 2009, Barišić 2013). In winter, Dunnocks hold feeding territories (Birkhead 1981) and they have high within and between season site fidelity in winter (Pons 2001, Spina \& Volponi 2009).

In Hungary, the ratio of overwintering and passage migrant Dunnocks vary considerably between years. Csörgô et al. (2001) showed that the migration was unimodal in autumn at the study site. The majority of migrant birds arrived during the first half of the migratory period and their stopover duration was short. Later arriving birds spent the whole winter in Ócsa in some years while not in others depending on the weather of previous year. In mild winters, birds remaining in the Carpathian Basin instead of migrating further south-west, may have selective advantage, since they could reach the breeding area earlier and could occupy better territories resulting higher numbers on the next winter. On the other hand, after cold winters, due to the high mortality of birds remaining in the Carpathian basin, the passage migrants had advantage. Costs and benefits of the two strategies change year by year as the winter weather condition fluctuate resulting in the coexistence of two alternative strategies.

In spring, Dunnocks presumably use the same routes as in autumn with no indication for loop migration. (Cramp 1988, Bairlein et al. 2014). The migration timing of Swedish Dunnocks shifted earlier (Fransson \& Hall-Karlsson 2008).

In Hungary, it is a common passage migrant from March to April in spring and from late September until early November in autumn (Hadarics \& Zalai 2008, Csörgő \& Kováts 2009). Dunnocks in Hungary may overwinter.

The Dunnocks are regular and common passage migrants at the Ócsa Bird Ringing Station, the source of data analysed in this paper.

Our aim is to provide a comprehensive overview of migration timing, body size measurements and inter-annual changes in these variables. Hopefully, these patterns will help formulate research questions and provide information for further higher level analyses. 
However, we do not aim to interpret the obtained results, merely draw attention to interesting patterns, that may be worth exploring in detail.

\section{Materials and methods}

\section{Bird ringing data}

The Ócsa Bird Ringing Station is situated in Central Hungary (N47.2970, E19.2104) in the Duna-Ipoly National Park in the immediate vicinity of Ócsa town. The study site is characterized by a post-glacial peat bog with mosaic of habitats that include open water surfaces, reedbeds, bushy vegetation and forests. It is situated in a humid continental transitional climate zone (for further details see Csörgő et al. 2016, ocsabirdringing.org ). Birds were trapped with standard mistnets located in standard locations throughout the study period. Trapping effort is seasonal and changed over the years (see Csörgô et al. 2016 for details).

The day of the year of first capture in spring and in autumn separately was considered as arrival (migration) timing of individual birds. Stopover duration was calculated as the difference of within season last and first captures excluding within day recaptures. Biometric measurements were taken following strictly standardized methods (Szentendrey et al. 1979, EURING 2015). Only data of the first captures were used in the analysis. We distinguished first calendar year birds (juveniles) from adults upon plumage characteristics (Cramp 1988, Svensson 1992, Demongin 2016), and we present all results according to these groups. We present data for spring and autumn migratory seasons separately; birds caught before the $120^{\text {th }}$ day of the year were considered to be spring migrants. A total of 11,617 Dunnocks were captured and ringed between March and November; 3144 in spring and 1734 adult and 6102 juvenile in autumn (the age of the rest of birds was not defined) in the study period of 1984-2015. This total value constitutes ca. $36 \%$ of the 31,900 Dunnocks ringed in Hungary in this period.

\section{Statistical methods}

To describe daily and yearly capture frequencies and the cumulative distribution of the date of first captures with recaptures, we used the functions of the ringR package (Harnos et al. 2015). Descriptive tables (mean, median, standard deviation (SD), minimum (min), maximum $(\max )$ values and sample size $(\mathrm{N})$ ) on the timing of migration, stopover duration, the length of wing, third primary and tail, and body mass were created by the data . table package (Dowle et al. 2013), which is highly effective in calculating summary statistics for different groups and subsets. The annual mean values of timing, body mass, wing-, third primary and tail lengths are plotted against time (year) on scatterplots. Loess smooth lines were fitted to highlight trends (Cleveland et al. 1992). The distribution of the same variables were represented with histograms and overplotted smooth histograms. Boxplots were used to show the body mass distribution by fat score categories. Fat and muscle score frequencies are shown using barplots. We distinguished seasons, and age groups 


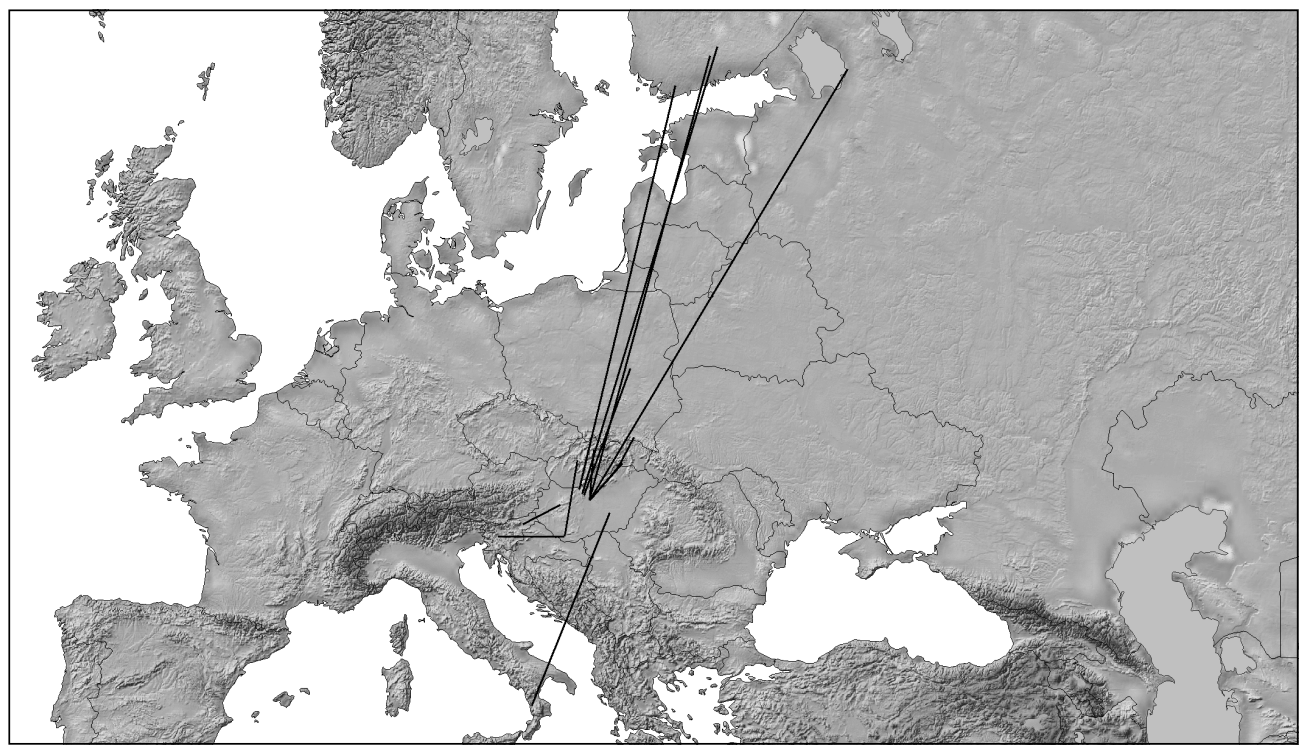

Figure 1. Foreign ring recoveries of Dunnocks. The data of birds ringed in Hungary and recovered abroad and the birds ringed abroad and recovered in Hungary are depicted

1. ábra Magyarországon jelölt és külföldön megkerült, illetve külföldön jelölt és Magyarországon megfogott erdei szürkebegyek

throughout the analyses. For more details on the analysis, please visit ocsabirdringing.org. All analyses were done in R 3.2.2 (R Core Team 2015).

\section{Results}

A total of 14 foreign recaptures were recorded between 1951 and 2016 in relation to Hungary (Figure 1). Annual capture and recapture frequencies at the study site are shown in Figure 2. Within-year capture and recapture frequencies, together with cumulative distribution of individual first and last captures are depicted in Figure 3, while their respective descriptive statistics are presented in Table 1-2. Changes in annual mean arrival dates throughout the study period and the distribution of within-year migration timing according to season and age are presented in Figure 4. The trend of annual mean wing lengths and the distribution of wing length measurements according to season and age are shown in Figure 5, while their respective descriptive statistics are presented in Table 3.

Third primary length (Figure 6, Table 4), tail length (Figure 7, Table 5) and body mass (Figure 8, Table 6) are presented in a similar fashion. Body mass in relation to season and age and fat scores are visualized with boxplots in Figure 9. Finally, the distribution of fat and muscle scores grouped by season and age can be found in Figure 9 b,d,f and Figure 10. 

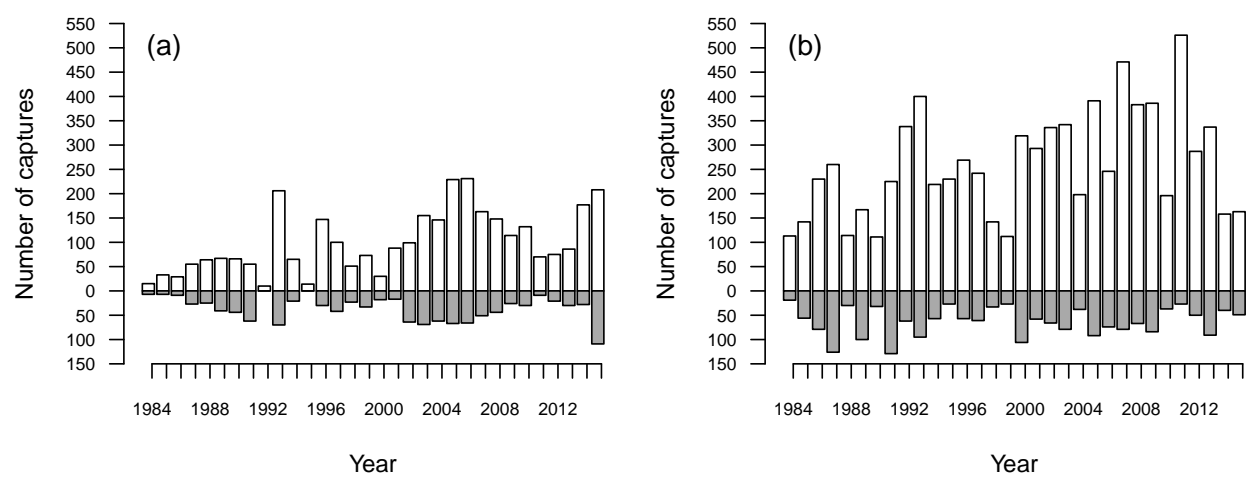

Figure 2. Annual capture (white bars) and recapture (grey bars) frequencies in spring (a), and in autumn (b)

2. ábra Éves fogás (fehér oszlopok) és visszafogás (szürke oszlopok) gyakoriságok tavasszal (a) és ősszel (b)
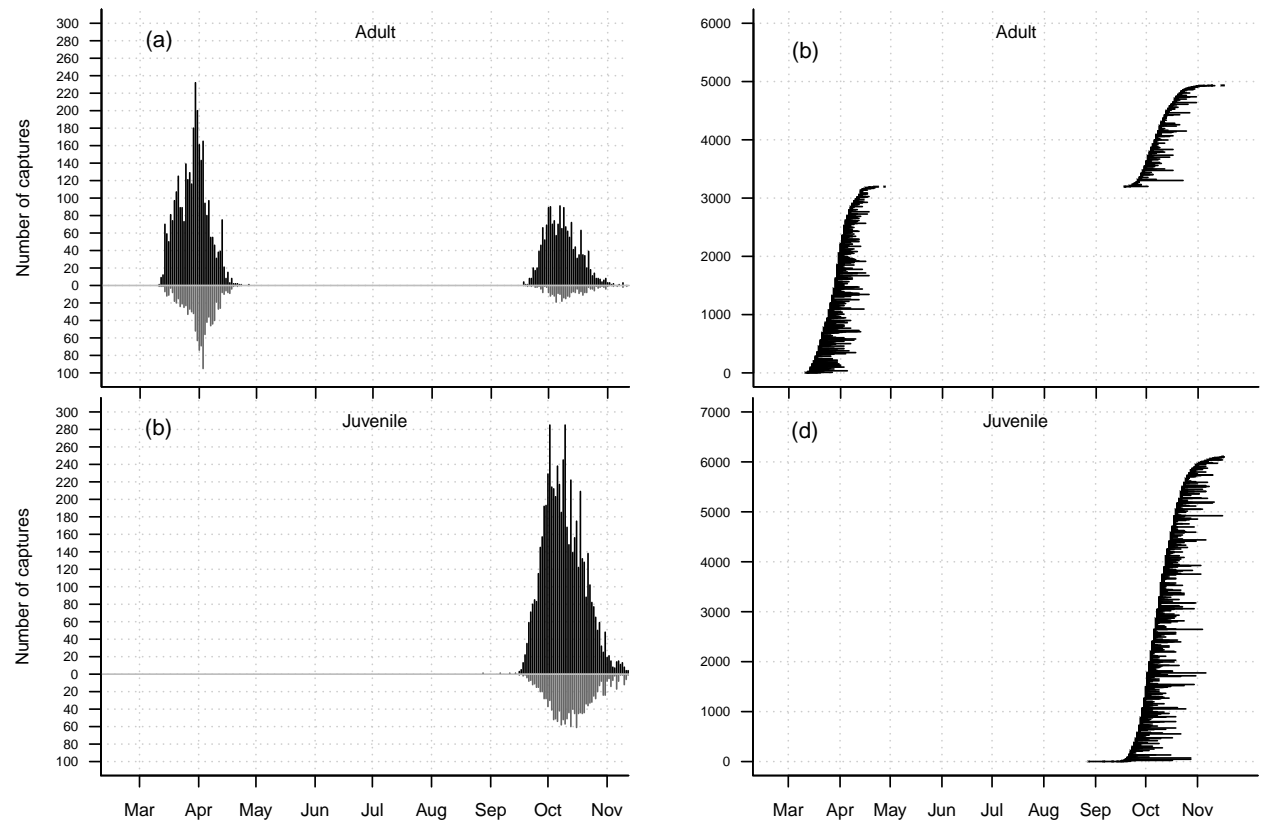

Figure 3. Within-year capture (black bars) and recapture (grey bars) frequencies (a, c) and cumulative distributions of individual first capture dates (b, d) according to age groups (horizontal lines: stopover durations)

3. ábra Éven belüli fogás (fekete oszlopok) és visszafogás (szürke oszlopok) gyakoriságok $(a, c)$ és az egyedek első megfogási idejének kumulatív eloszlása (b, d) korcsoportonként (vízszintes vonalak: tartózkodási idők) 
Table 1. Descriptive statistics of migration timing (day of the year)

1. táblázat A vonulás időzítés (év napja) leíró statisztikái

\begin{tabular}{|l|l|c|c|c|c|c|c|}
\hline Season & Age & Mean & Median & SD & Min & Max & N \\
\hline spring & adult & 87.9 & 88 & 7.8 & 70 & 117 & 3144 \\
\hline autumn & adult & 281.1 & 280 & 8.8 & 261 & 320 & 1734 \\
\hline autumn & juvenile & 282.4 & 282 & 10.6 & 240 & 320 & 6102 \\
\hline
\end{tabular}

Table 2. Descriptive statistics of stopover duration (day)

2. táblázat A tartózkodási idő (nap) leíró statisztikái

\begin{tabular}{|l|l|c|c|c|c|c|c|}
\hline Season & Age & Mean & Median & SD & Min & Max & N \\
\hline spring & adult & 5.2 & 4 & 4.4 & 1 & 23 & 682 \\
\hline autumn & adult & 4.9 & 3 & 4.6 & 1 & 30 & 252 \\
\hline autumn & juvenile & 5.6 & 4 & 5.4 & 1 & 39 & 891 \\
\hline
\end{tabular}

Table 3. Descriptive statistics of wing length $(\mathrm{mm})$

3. táblázat A szárnyhossz ( $\mathrm{mm}$ ) leíró statisztikái

\begin{tabular}{|l|l|c|c|c|c|c|c|}
\hline Season & Age & Mean & Median & SD & Min & Max & N \\
\hline spring & adult & 68.7 & 69 & 2.1 & 61 & 76 & 3033 \\
\hline autumn & adult & 69.3 & 69 & 2.0 & 62 & 76 & 1699 \\
\hline autumn & juvenile & 68.4 & 68 & 1.9 & 62 & 75 & 5974 \\
\hline
\end{tabular}

Table 4. Descriptive statistics of third primary length ( $\mathrm{mm})$

4. táblázat A harmadik evező hosszának $(\mathrm{mm})$ leíró statisztikái

\begin{tabular}{|l|l|c|c|c|c|c|c|}
\hline Season & Age & Mean & Median & SD & Min & Max & N \\
\hline spring & adult & 52.1 & 52 & 1.8 & 45 & 59 & 2883 \\
\hline autumn & adult & 52.4 & 52 & 1.8 & 47 & 59 & 1628 \\
\hline autumn & juvenile & 51.6 & 52 & 1.7 & 45 & 59 & 5534 \\
\hline
\end{tabular}

Table 5. Descriptive statistics of tail length $(\mathrm{mm})$

5. táblázat A farokhossz ( $\mathrm{mm}$ ) leíró statisztikái

\begin{tabular}{|l|l|c|c|c|c|c|c|}
\hline Season & Age & Mean & Median & SD & Min & Max & N \\
\hline spring & adult & 58.5 & 58 & 2.7 & 50 & 70 & 2975 \\
\hline autumn & adult & 59.7 & 60 & 2.7 & 51 & 69 & 1689 \\
\hline autumn & juvenile & 58.5 & 58 & 2.7 & 50 & 70 & 5885 \\
\hline
\end{tabular}

Table 6. Descriptive statistics of body mass ( $\mathrm{g}$ )

6. táblázat A testtömeg (g) leíró statisztikái

\begin{tabular}{|l|l|c|c|c|c|c|c|}
\hline Season & Age & Mean & Median & SD & Min & Max & N \\
\hline spring & adult & 18.9 & 18.8 & 1.6 & 14.5 & 26.1 & 3077 \\
\hline autumn & adult & 19.1 & 19.0 & 1.6 & 15.3 & 25.1 & 1709 \\
\hline autumn & juvenile & 19.2 & 19.0 & 1.7 & 14.6 & 27.0 & 6001 \\
\hline
\end{tabular}



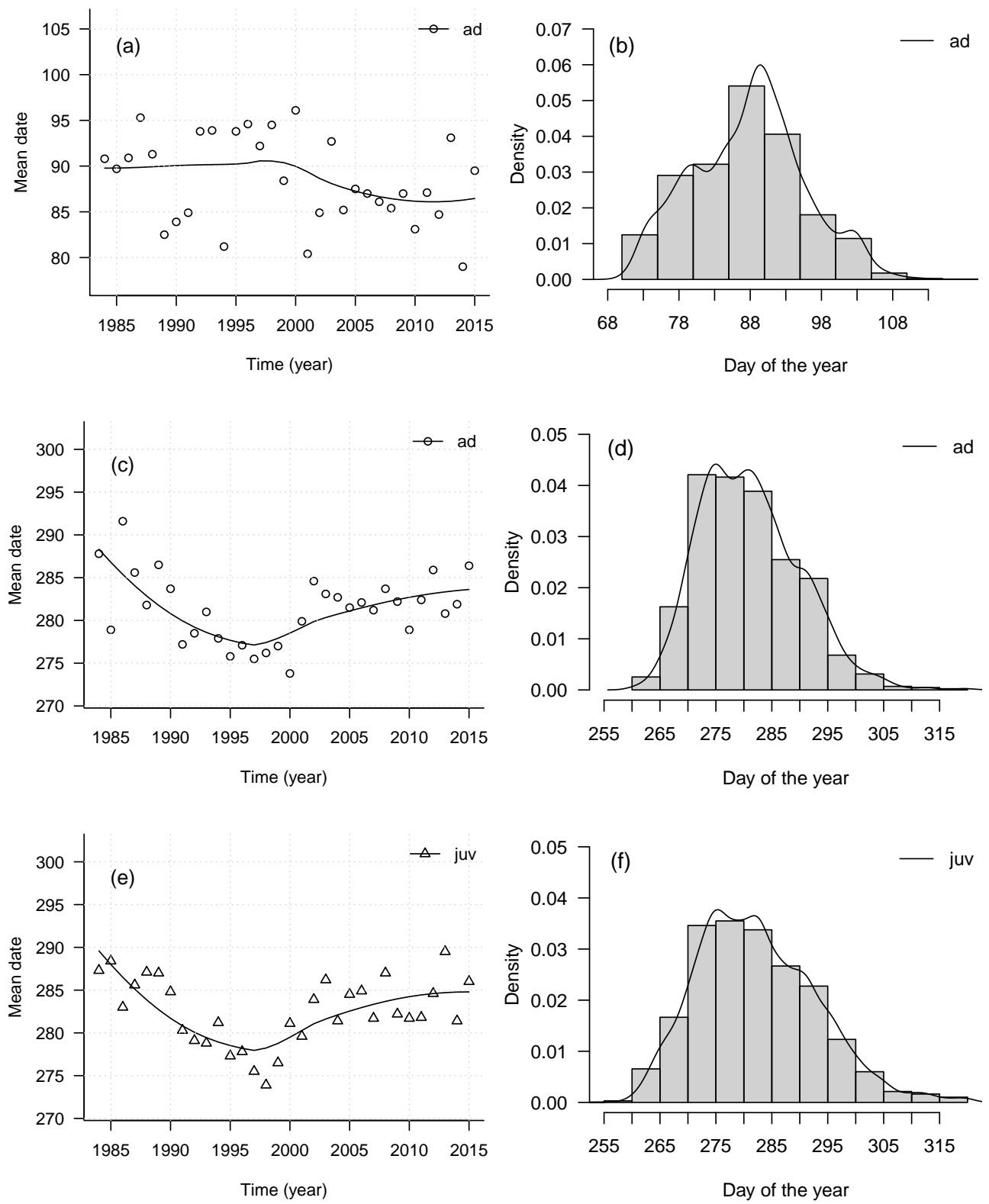

Figure 4. Annual mean migration timing (day of the year) throughout the study period and histograms/smoothed histograms of timing in spring $(a-b)$ and in autumn (c- $f$ )

4. ábra Az éves átlagos vonulás időzítés (év napja) a vizsgálati időszakban és az időzítés hisztogramja/simított hisztogramja tavasszal (a-b) és ősszel (c-f) 

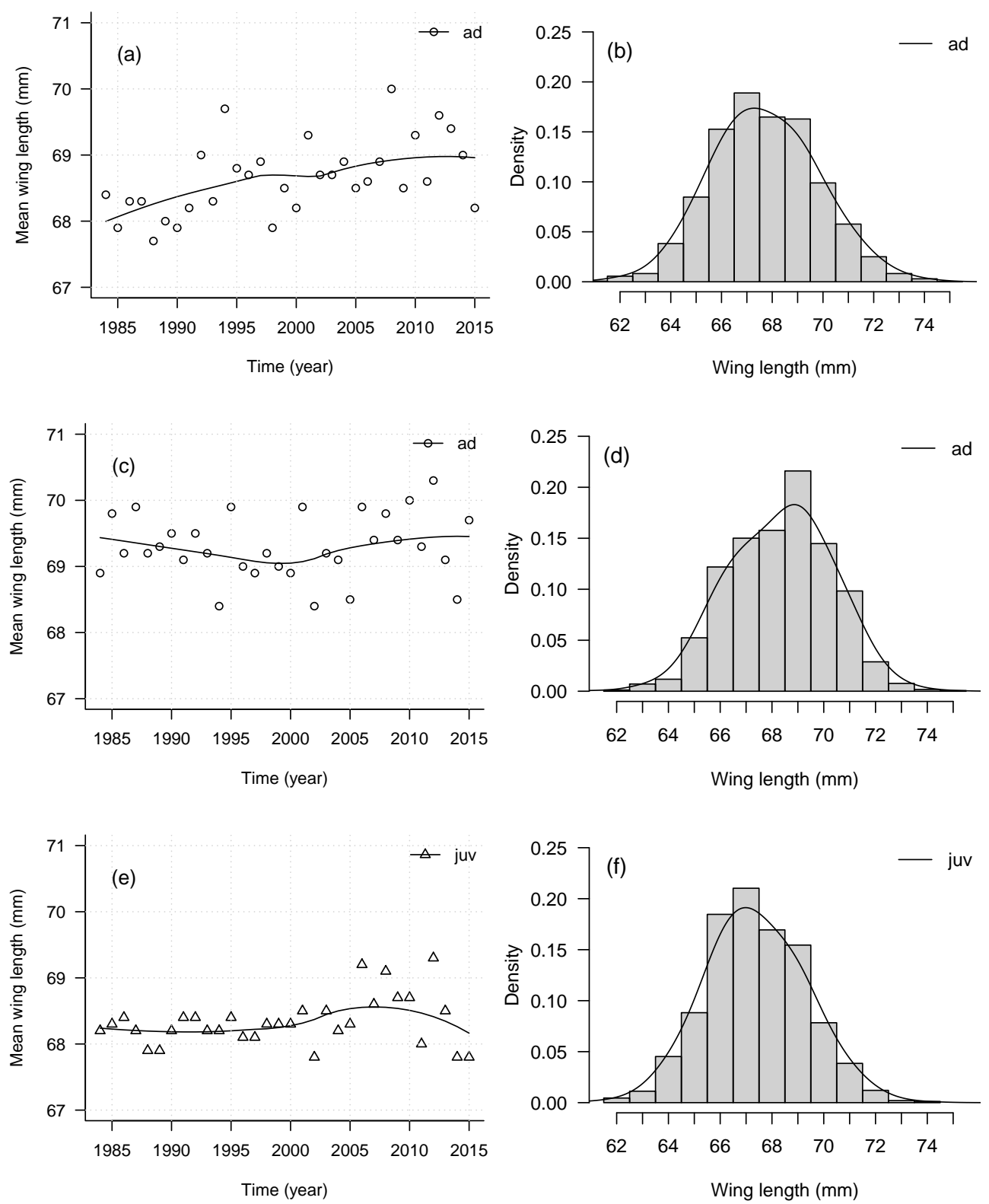

Figure 5. Annual mean wing length $(\mathrm{mm})$ throughout the study period and histograms/smoothed histograms of wing length in spring $(a-b)$ and in autumn (c- $f$ )

5. ábra Az éves átlagos szárnyhossz $(\mathrm{mm})$ a vizsgálati időszakban és a szárnyhossz hisztogramja/simított hisztogramja tavasszal $(a-b)$ és ősszel (c-f) 

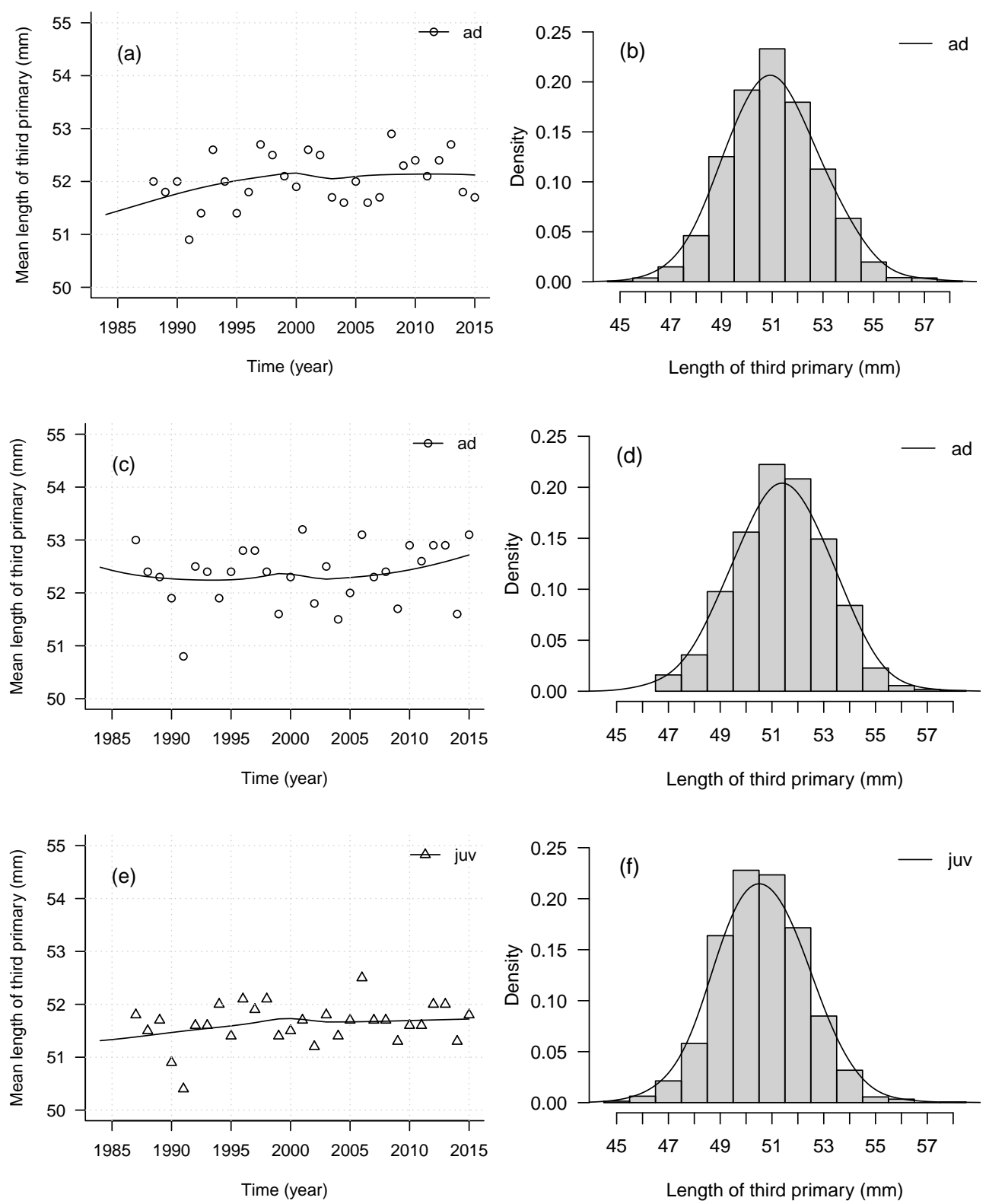

Figure 6. Annual mean third primary length $(\mathrm{mm})$ throughout the study period and histograms/smoothed histograms of third primary length in spring $(a-b)$ and in autumn (c-f)

6. ábra Az éves átlagos harmadik evező hossz $(\mathrm{mm})$ a vizsgálati időszakban és a harmadik evező hosszának hisztogramja/simított hisztogramja tavasszal (a-b) és ősszel (c-f) 

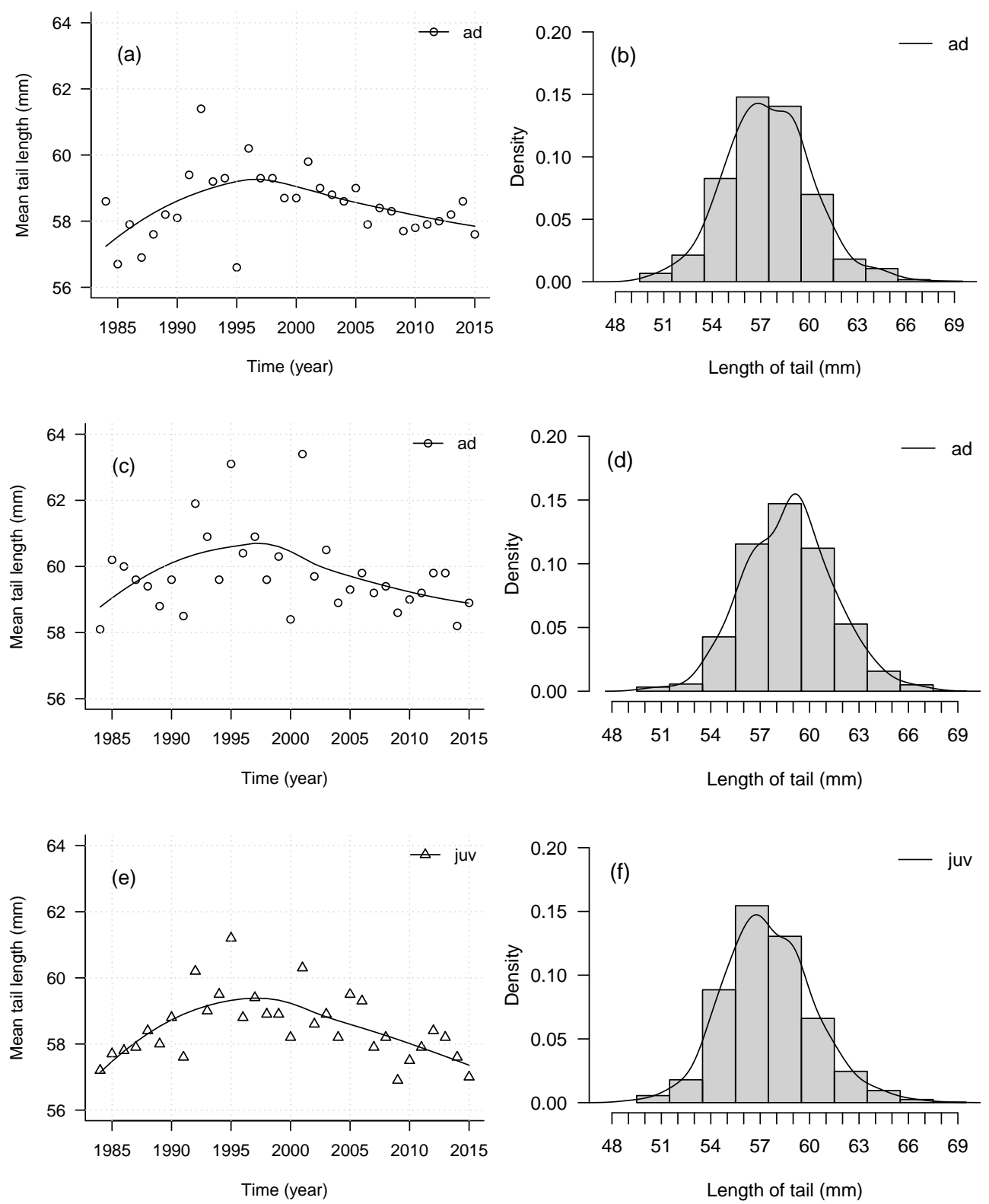

Figure 7. Annual mean tail length $(\mathrm{mm})$ throughout the study period and histograms/smoothed histograms of third primary length in spring $(a-b)$ and in autumn (c-f)

7. ábra Az éves átlagos farokhossz $(\mathrm{mm})$ a vizsgálati időszakban és a farokhossz hisztogramja/simított hisztogramja tavasszal (a-b) és ősszel (c-f) 

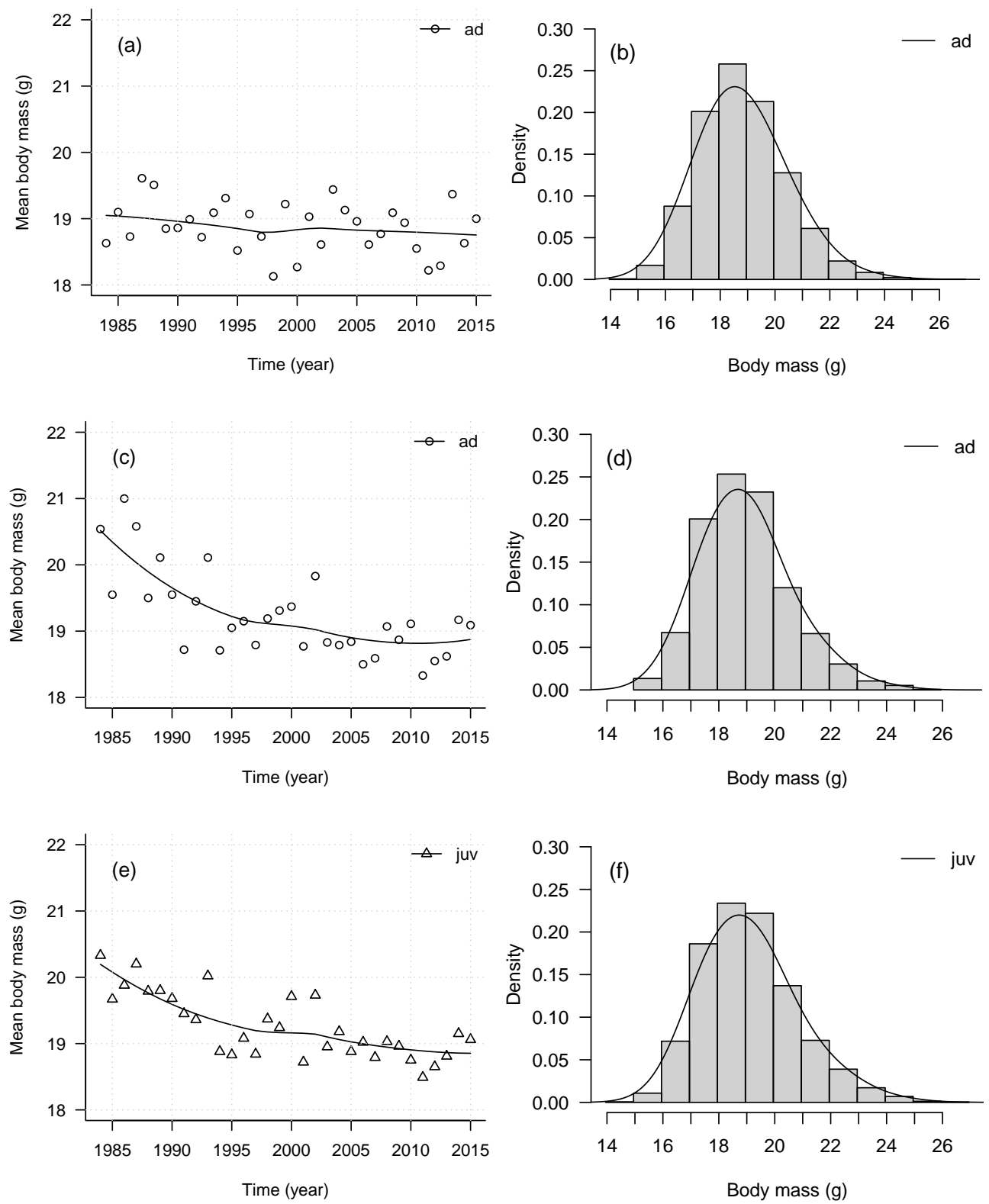

Figure 8. Annual mean body mass ( $\mathrm{g}$ ) throughout the study period and histograms/smoothed histograms of body mass in spring (a-b) and in autumn (c-f)

8. ábra Az éves átlagos testtömeg (g) a vizsgálati időszakban és a testtömeg hisztogram$\mathrm{ja}$ /simított hisztogramja tavasszal (a-b) és ősszel (c-f) 

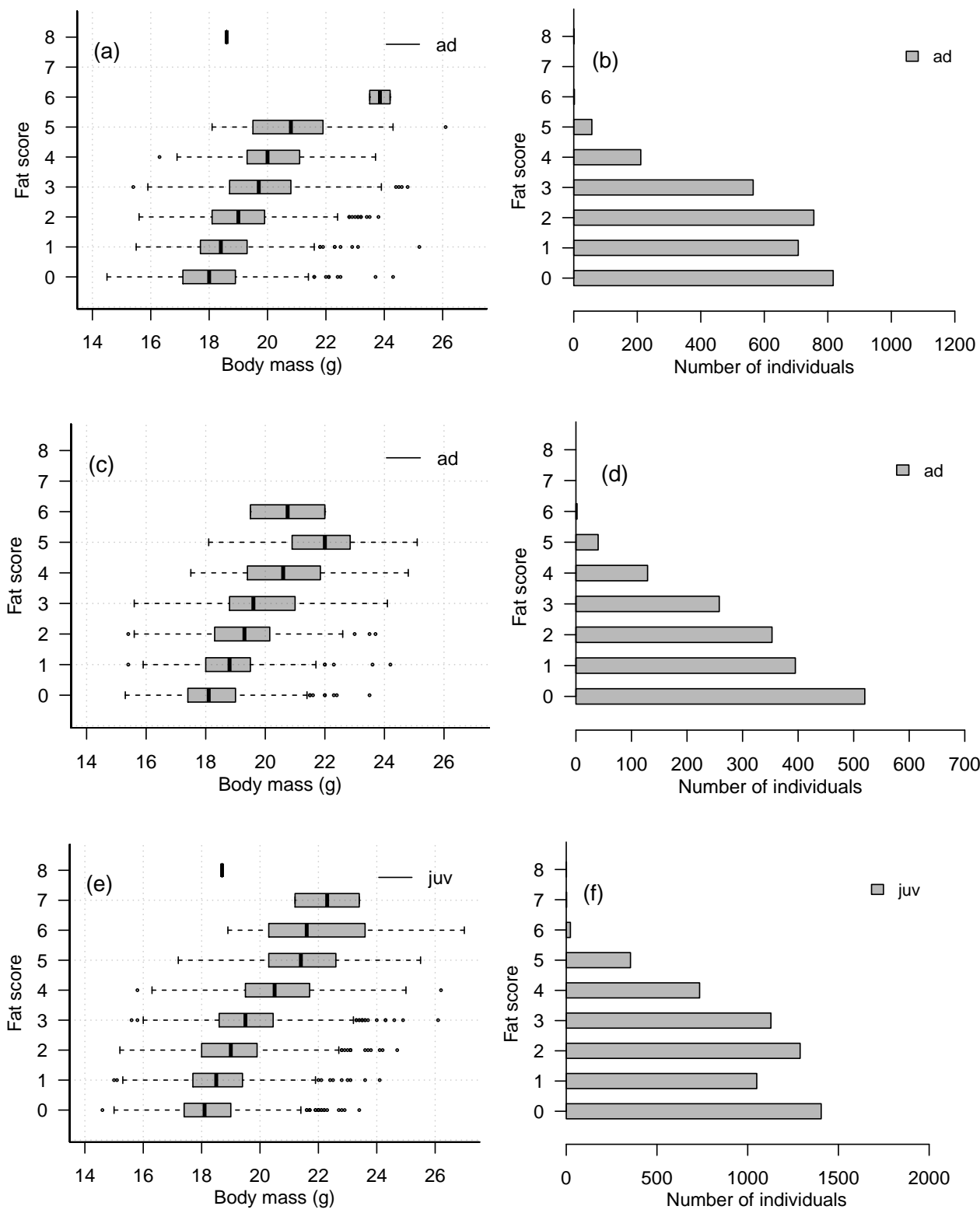

Figure 9. Boxplots of body mass according to fat score, and fat score frequencies in spring $(a-b)$ and in autumn (c-f)

9. ábra A testtömeg boxplot-ja zsírkategóriánként és a zsírkategóriák gyakoriságai tavasszal $(a-b)$ és ősszel (c-f) 

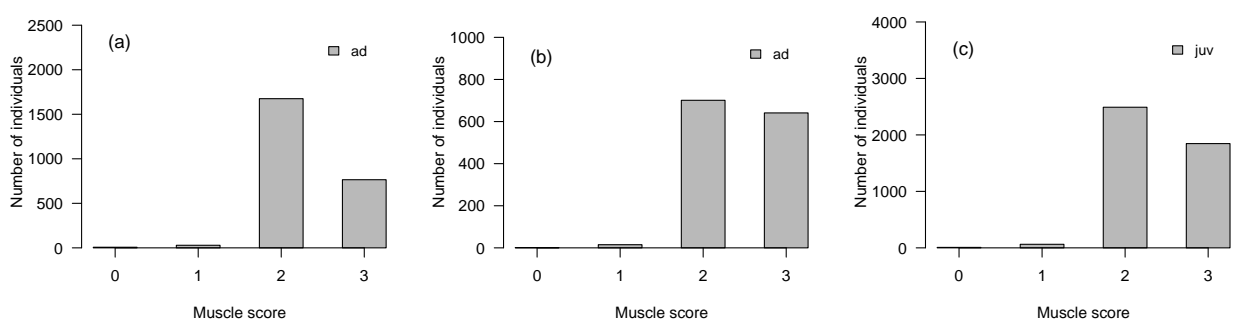

Figure 10. Muscle score frequencies in spring (a) and in autumn (b-c) 10. ábra Izom kategória gyakoriságok tavasszal (a) és ősszel $(b-c)$

\section{Discussion}

The exploratory analyses of timing and morphometrics of the Dunnock revealed several patterns of interest. Apparently, there is considerable variation in inter-annual capture and recapture frequencies (Figure $2 a, b$ ) with disproportionally more recaptures (Figure $2 a$ ) in spring. The stopover durations are similar in all cases (Figure 3 b,d, Table 2).

The birds appear in greater numbers during the autumn migration, when the amount of juveniles greatly exceeds the amount of the adults. Evidently, the lack of captures of all age groups during the breeding season corroborates that there is no local breeding population at the study site (Figure $2 a, b$ ).

While the spring migration timing appears to be more or less constant (with a slight decrease in the last decade (Figure 4 a), the autumn timing hits a bottom in the late 1990's. Timing of the adults and the juveniles in the autumn are rather similar (Figure $4 c, e$ ). The distribution of arrival timing in both seasons are seemingly unimodal (Figure $4 b, d, f$ ). There is no apparent, relevant trends over the years neither in the wing length nor in the third primary length of the birds (Figures 5-6 a,c,e).

Tail length seems to peak around the late 1990's, although with a considerable interannual variation (Figure 7 a,c,e). The mean body mass seems to be constant over the years (Figure $8 a$ ), however a decreasing trend can be observed during the autumn season (Figure $8 c, d)$.

All the biometric variables have unimodal distribution indicating that there is no considerable size difference between the sexes (Figure 5-8 a,c,e).

The fat and muscle score distributions suggest that the birds build their muscles rather than accumulate fat reserves (Figures 9-10).

Our results show that comprehensive exploratory analyses may reveal intriguing patterns, which may be investigated in more detail in the future. We however emphasize that although the temporal extent of the data reported here is considerably large, all information presented here derives from a single location and thus has to be interpreted accordingly. Nonetheless, we hope that our results will help researchers conducting comparative or meta-analyses with baseline data and may also encourage others to report their data in a similar fashion. We also seek cooperation with interested parties and are willing to share all data reported here. Please contact the corresponding author for details. 


\section{Acknowledgments}

The authors express their gratitude for the work of all the volunteers who collected data at the Ócsa Bird Ringing Station throughout the years. We are grateful for our colleagues especially for Márton Demeter - who helped us develop the codes and for Lajos Rózsa and János Kis, who helped us improve the manusript. This work was supported by the National Scientific Research Fund of Hungary (OTKA under Grant No. 108571).

\section{References}

Bairlein, F., Dierschke, J., Dierschke, V., Salewski, V., Geiter, O., Hüppop, K., Köppen, U. \& Fiedler, W. 2014. Atlas des Vogelzugs [Bird Migration Atlas]. - AULA-Verlag, pp. 461-463. (in German with English Summary)

Barišić, S. 2013. Crnoglava muharica, Pied Flycatcher. - In: Kralj, J., Barišić, S., Tutiš, V. \& Ćiković, D. (eds.) Atlas selidbaptica Hrvatske [Croatian Bird Migration Atlas]. - Croatian Academy of Sciences and Arts, Zagreb, pp. 152-153. (in Croatian with English Summary)

Benvenuti, S. \& Ioalè, P. 1980. Homing experiments with birds displaced from their wintering ground. Journal of Ornithology 121(3): 281-286. DOI: 10.1007/bf01647618

Bingman, V. P. \& Wiltschko, W. 1988. Orientation of Dunnocks (Prunella modularis) at sunset. Ethology 77(1): 1-9. DOI: 10.1111/j.1439-0310.1988.tb00187.x

BirdLife Hungary 2016. Magyarország madarai: Erdei szürkebegy [Birds of Hungary: the Dunnock]. Magyar Madártani és Természetvédelmi Egyesület [BirdLife Hungary]. http://www.mme.hu/ magyarorszagmadarai/madaradatbazis-prumod, downloaded on 11 December 2016. (in Hungarian)

BirdLife International 2016. Prunella modularis. The IUCN Red List of Threatened Species 2016: e.T22709308A87938122. DOI: 10.2305/IUCN.UK.2016-3.RLTS.T22718651A88047392.en

Birkhead, M. 1981. The social behaviour of the Dunnock Prunella modularis. - Ibis 123(1): 75-84. DOI: $10.1111 / \mathrm{j} .1439-0310.1988 . t b 00187 . x$

Bønløkke, J., Madsen, J. J., Thorup, K., Pedersen, K. T., Bjerrum, M. \& Rahbek, C. 2006. Dansk trækfugleatlas [Danish Bird Migration Atlas]. - Rhodos, Humlebæk, pp. 686-689. (in Danish with English Summary)

Cleveland, W. S., Grosse, E. \& Shyu, W. M. 1992. Local regression models. - In: Chambers, J. \& Hastie, T. (eds.) Statistical Models in S. - Pacific Grove, California, pp. 309-376.

Cramp, S. 1988. Handbook of the Birds of the Western Palearctic. Vol. 5. - Oxford University Press, Oxford, pp. 548-560.

Csörgó, T., Harnos, A., Rózsa, L., Karcza, Zs. \& Fehérvári, P. 2016. Detailed description of the Ócsa Bird Ringing Station, Hungary. - Ornis Hungarica 24(2): 91-108. DOI: 10.1515/orhu-2016-0018

Csörgő, T. \& Kováts, L. 2009. Dunnock. - In: Csörgő, T., Karcza, Zs., Halmos, G., Magyar, G., Gyurácz, J., Szép, T., Bankovics, A., Schmidt, A. \& Schmidt, E. (eds.) Magyar madárvonulási atlasz [Hungarian Bird Migration Atlas]. - Kossuth Kiadó Zrt., Budapest, pp. 437-439. (in Hungarian with English Summary)

Csörgő, T., Móra, V. \& Miklay, Gy. 2001. Autumn migration and wintering of Dunnock (Prunella modularis) in Hungary. - Ring 23(1-2): 99-107. http://www.wbwp-fund.eu/ring/pdf/23-1-2/csor.pdf

Davies, N. 1985. Cooperation and conflict among Dunnocks, Prunella modularis, in a variable mating system. - Animal Behaviour 33(2): 628-648. DOI: 10.1016/s0003-3472(85)80087-7

Davies, N. \& Lundberg, A. 1984. Food distribution and a variable mating system in the Dunnock, Prunella modularis. - Journal of Animal Ecology 53(3): 895-912. DOI: 10.2307/4666

Davies, N. B. 1986. Reproductive success of Dunnocks, Prunella modularis, in a variable mating system. 1. factors influencing provisioning rate, nestling weight and fledging success. - Journal of Animal Ecology 55(1): 123-138. DOI: 10.2307/4697 
Davies, N. B. \& Houston, A. I. 1986. Reproductive success of Dunnocks, Prunella modularis, in a variable mating system. 2. Conflicts of interest among breeding adults. - The Journal of Animal Ecology 55(1): 139-154. DOI: 10.2307/4698

Demongin, L. 2016. Identification guide to birds in the hand. - Beauregard-Vernon, pp. 243-244.

Dowle, M., Short, T. \& Lianoglou, S. 2013. data.table: Extension of data.frame for fast indexing, fast ordered joins, fast assignment, fast grouping and list columns. - R package version 1.8.10; with contributions from Srinivasan, S., Lianoglou, A. and Saporta, R. http://CRAN.R-project.org/package= data.table

EURING 2015. The EURING Exchange Code 2000 Plus. - The European Union for Bird Ringing, Thetford, U.K. http://www.euring.org/data_and_codes/euring_code_list/index.html

Fransson, T. \& Hall-Karlsson, S. 2008. Svensk Ringmärkningsatlas Vol. 3. [Swedish Bird Ringing Atlas, Vol. 3.]. - Naturhistoriska Riksmuseet \& Sveriges Ornitologiska Förening, Stockholm, pp. 52-55. (in Swedish with English Summary)

Gienapp, P., Leimu, R. \& Merilä, J. 2007. Responses to climate change in avian migration time microevolution versus phenotypic plasticity. - Climate Research 35: 25-35. DOI: 10.3354/cr00712

Hadarics, T. \& Zalai, T. 2008. Nomenclator avium Hungariae - Magyarország madarainak névjegyzéke [An annotated list of the birds of Hungary]. - Magyar Madártani és Természetvédelmi Egyesület, Budapest, pp. 173-174. (in Hungarian)

Harnos, A., Csörgő, T. \& Fehérvári, P. 2016. Hitchhikers' guide to analysing bird ringing data. Part 2. Ornis Hungarica 24(1): 172-181. DOI: 10.1515/orhu-2016-0010

Harnos, A., Fehérvári, P. \& Csörgő, T. 2015. Hitchhikers' guide to analysing bird ringing data. Part 1. Ornis Hungarica 23(2): 163-188. DOI: 10.1515/orhu-2015-0018

Hartly, I. R. 2002. Dunnock. - In: Werham, C., Toms, M., Marchant, J., Clarke, J., Siriwardena, G. \& Baillie, S. (eds.) The Migration Atlas: Movements of the Birds of Britain and Ireland. - T \& AD Poyser, London, pp. 496-497.

Hatchwell, B. \& Davies, N. 1992. An experimental study of mating competition in monogamous and polyandrous Dunnocks, Prunella modularis: I. mate guarding and copulations. - Animal Behaviour 43(4): 595-609. DOI: 10.1016/s0003-3472(05)81019-x

Hatchwell, B. J. 2005. European Pied Flycatcher. - In: del Hoyo, J., Elliott, A. \& Christie, D. A. (eds.) Handbook of the Birds of the World, Vol. 10. - Lynx Edicion Publications, pp. 512-513.

Hatchwell, B. J. \& Davies, N. B. 1990. Provisioning of nestlings by Dunnocks, Prunella modularis, in pairs and trios: Compensation reactions by males and females. - Behavioral Ecology and Sociobiology 27(3): 199-209. DOI: 10.1007/BF00180304

Hromádko, M. 2008. Pvuška modrá, Hedge Accentor (Dunnock). - In: Cepak, J., Klvaňa, P., Škopek, J., Schröpfer, L., Jelínek, M., Hořák, D., Formánek, J. \& Zárybnický, J. (eds.) Atlas migrace ptáků České a Slovenské republiky [Chech and Slovak Bird Migration Atlas]. - Aventinum, Praha, pp. 365-367. (in Slovakian with English Summary)

Ioale, P. \& Benvenuti, S. 1983. Site attachment and homing ability in passerine birds. - Monitore Zoologico Italiano - Italian Journal of Zoology 17(3): 279-294. DOI: 10.1080/00269786.1983.10736429

Magyar, G., Hadarics, T. \& Waliczky, Z. 1998. Nomenclator avium Hungariae: An annotated list of the birds of Hungary. - KTM Természetvédelmi Hivatal Madártani Intézete, Magyar Madártani és Természetvédelmi Egyesület, Winter Fair, Budapest - Szeged, p. 101.

Malczewski, S. A. \& Pukinsky, J. B. 1983. Birds of the Leningrad region and adjacent territories: History, biology, conservation. - Leningrad University Publishing, Leningrad, pp. 337-341. (in Russian)

Marra, P. P., Francis, C. M., Mulvihill, R. S. \& Moore, F. R. 2004. The influence of climate on the timing and rate of spring bird migration. - Oecologia 142(2): 307-315. DOI: 10.1007/s00442-004-1725-x

Pons, P. 2001. The wintering of migrant Dunnocks Prunella modularis in two Mediterranean habitats after fire. - Bird Study 48(1): 68-75. DOI: 10.1080/00063650109461204

R Core Team 2015. R: A Language and Environment for Statistical Computing. - R Foundation for Statistical Computing, Vienna, Austria https://www.R-project.org/ 
Robinson, R. A., Julliard, R. \& Saracco, J. F. 2009. Constant effort: Studying avian population processes using standardised ringing. - Ringing \& Migration 24(3): 199-204. DOI: $10.1080 / 03078698.2009 .9674392$

Santos, E. S. A. \& Nakagawa, S. 2013. Breeding biology and variable mating system of a population of introduced Dunnocks (Prunella modularis) in New Zealand. - PLoS ONE 8(7): e69329. DOI: 10.1371/journal.pone.0069329

Schaub, M. \& Jenni, L. 2000. Fuel deposition of three passerine bird species along the migration route. Oecologia 122(3): 306-317. DOI: 10.1007/s004420050036

Schaub, M., Jenni, L. \& Bairlein, F. 2008. Fuel stores, fuel accumulation, and the decision to depart from a migration stopover site. - Behavioral Ecology 19(3): 657-666. DOI: 10.1093/beheco/arn023

Schubert, M., Fedrigo, A. \& Massa, R. 1986. Timing and pattern of the post-breeding migration of some species of passerines through Lombardy, Northern Italy. - Ringing \& Migration 7(1): 15-22. DOI: $10.1080 / 03078698.1986 .9673874$

Schwabl, H., Gwinner, E., Benvenuti, S. \& Ioalè, P. 1991. Exposure of Dunnocks (Prunella modularis) to their previous wintering site modifies autumnal activity pattern: Evidence for site recognition? Ethology 88(1): 35-45. DOI: 10.1111/j.1439-0310.1991.tb00261.x

Sokolov, L. V., Markovets, M. Y. \& Morozov, Y. G. 1999. Long-term dynamics of the mean date of autumn migration in passerines on the Courish Spit of the Baltic Sea. - Avian Ecolgy and Behaviour 2: 1-18. https://www.zin.ru/rybachy/sokolov-pdf/1999c.pdf

Spina, F. \& Volponi, S. 2009. Atlante della migrazione degli uccelli in Italia. Vol. 2.: Passeriformi [Italian Bird Migration Atlas Vol. 2.: Passeriformes]. - Ministero dell'Ambiente e della Tutela del Territorio e del Mare, Roma (Italy) ISPRA, pp. 136-143. (in Italian with English Summary)

Svensson, L. 1992. Identification Guide to European Passerines - Ugga, Stockholm, $4^{\text {th }}$ ed., pp. 227-231.

Szentendrey, G., Lövei, G. \& Kállay, Gy. 1979. Az Actio Hungarica madárgyưrúző tábor mérési módszerei [Measuring methods in the bird ringing camps of Actio Hungarica]. - Állattani Közlemények 66: 161-166. (in Hungarian)

Tøttrup, A. P., Rainio, K., Coppack, T., Lehikoinen, E., Rahbek, C. \& Thorup, K. 2010. Local temperature fine-tunes the timing of spring migration in birds. - Integrative and Comparative Biology 50(3): 293-304. DOI: 10.1093/icb/icq028

Valkama, J., Saurola, P., Lehikoinen, A., Lehikoinen, E., Piha, M., Sola, P. \& Velmala, W. 2014. Suomen Rengastusatlas. Osa II. [The Finnish Bird Ringing Atlas Vol. II.]. - Finnish Museum of Natural History and Ministry of Environment, Helsinki, pp. 391-395. (in Finnish with English Summary)

Vogel, R. \& Tuomenpuro, J. 1997. Dunnock Prunella modularis - In: Hagemeijer, W. J. M. \& Blair, M. J. (eds.) The EBCC Atlas of European breeding birds: Their distribution and abundance. - T \& AD Poyser, London, pp. 506-507.

Zaniewicz, G. \& Busse, P. 2008. Autumn migration dynamics and biometrical differentiation of the Dunnock (Prunella modularis) passing the southern Baltic coast. - Ring 30(1-2): 31-54.

DOI: $10.2478 / \mathrm{v} 10050-008-0006-1$

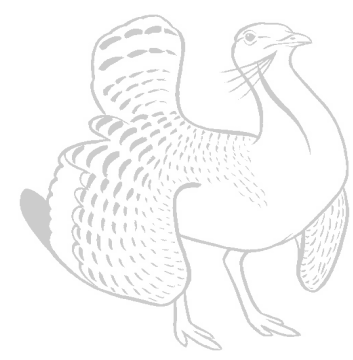

